Seema Arora-Jonsson

\title{
Discordant Connections: Discourses on Gender and Grassroots Activism in Two Forest Communities in India and Sweden
}

\author{
Winner of the 2009 Catharine Stimpson Prize
}

n 2005 Wangari Maathai was awarded the Nobel Peace Prize, and the issue of women's rights in environmental matters appeared briefly on the international agenda. In a joint article, Maathai and Lena Sommestad, both active in the network of female environmental ministers, emphasized that women's interests must be taken into account when environmental policies are formulated (Sommestad and Maathai 2005). They position equality between men and women as a crucial development question-necessary for effective and sustainable development, especially in poorer countries.

The importance of gender equality and of the relationship between third-world women and the environment is evident. Development and a certain standard of welfare make these issues appear to be less urgent in a wealthier country such as Sweden. However, my research with women's groups in forest communities in India and Sweden showed otherwise. First, questions of gender and power in environmental management are relevant not only in a poorer country such as India but also in a richer country such as Sweden. In the latter they can take forms that make gender discrimination more difficult to contest. Second, development discourses about equality and empowerment of oppressed third-world women not only affect how gender equality is conceptualized and practiced in the

I would like to thank Alison Wylie for helping me structure my arguments for this article and Louise Fortmann for all her support and important insights. For reading the draft at various stages and giving invaluable feedback, I would like to thank Stefan Jonsson, Mary John, Nivedita Menon, and the seminar group at the Centre for Gender Research at Uppsala University, especially Katarina Petersson for long-distance help with references. Thanks also to the Signs reviewers and the journal editors, who have helped to improve the manuscript with their questions and advice.

[Signs: Journal of Women in Culture and Society 2009, vol. 35, no. 1]

(C) 2009 by The University of Chicago. All rights reserved. 0097-9740/2009/3501-0001\$10.00 
global South but also shape the possibilities for gender equality in the North. Understanding how this takes place opens an opportunity for interruption in an order and in a space (a global/social order and a developed and gender-equal space) that appears to have become narrower under the umbrella of development, welfare, and growth. It brings into question the category of development not only in a Southern but also in a Northern context, where the North, especially Sweden, is taken as a referent for development and gender equality.

In this article, I trace some of the contradictions and connections in the ways in which gender equality and women's empowerment are conceptualized in women's struggles in villages in the Nayagarh district in Orissa, India, and in the village of Drevdagen in western Sweden. Examples of women's grassroots activism from the two case studies give material form to abstract discussions about the possibilities for women's agency in different cultural settings. In both study sites, women in villages in rural and peripheral areas (in relation to policy- and decision-making centers) formed organizations parallel to the male-dominated organizations in their villages. In absolute terms, the women in Sweden were far better off: in health care, wealth, availability of food, choice to work and marry, and geographical mobility. Yet their meetings as women were hedged with ambiguity and sparked resistance in the village. Power and discrimination were veiled and subtle in Sweden. Paradoxically, the rhetoric of gender equality that is pervasive in Sweden serves to mask forms of subordination and makes it difficult to question the purported neutrality of given structures. The Indian women were more vocal about discrimination against them. Outside intervention in gender issues was acceptable in the Indian development context but was regarded as interference in what were considered to be personal relations in the case in Sweden. Gender and environmental relations were conceptualized in ways that were specific to each context but also carried the impress of outside forces. Strong normative assumptions about development, gender equality, and empowerment resonated with one another in both places. A complex movement of ideas at the global level-about what it means to be developed, rural or urban, empowered, and independent-found expression in the everyday practice of development in both places.

\section{A relational analysis}

Third-world feminists and others have challenged universal conceptions of gender. They emphasize that understanding the different ways in which meanings are produced and challenged reveals the complex and specific 
political choices that caution us against ahistorical and universalizing categories (see Mohanty 2003). Gender is a historically and culturally variable category. Yet, as my studies show, overlapping discursive contexts and recurring practices in the politics of everyday life also reveal links between distant places, links that in turn pose new questions for the study of gender and power in an interconnected world. Ideas about gender and gender equality are formed by various local material practices, but as the two cases indicate, they are also a hybrid of different influences. Despite shifting meanings and contextual relations, the practices of gender equality in particular places echo one another, are marked by the histories and relationships of power that structure the world, and are linked to ideas about modernity and development. According to Cindi Katz, situated knowledge assumes knowledge at a single point, the knowing subject. This, she argues, has tended to facilitate a collapse of dimensionality. She calls instead for a topography to elucidate the intersection of processes with others elsewhere and thereby inspire a different kind of politics, one in which crossing space and "jumping scale" are obligatory rather than overlooked (2001, 1230-31).

Crossing space by reading stories from India and Sweden made it possible for me to develop a relational analysis of the particular places. The methodology I employed to study different analytic frameworks and different geographies included three elements: freezing time, reversing the gaze from North to South, and embracing critical subjectivity (AroraJonsson 2005, 60-61). I scrutinized language and actions as indications of underlying structures of meaning, indications that tell us not just about the person speaking and acting but about a wider discursive context that goes beyond the micropolitics of the villages. I studied not only collective action but also how individual women define their subjective positions within a collective. I used the case study from India as a frame of reference rather than accepting conventional assumptions of gender equality where Northern principles are the reference points. As a researcher working in both the global North and the global South, I became aware of a global discourse on gender and the need for reflexivity in situations where I am both an academic and an active participant.

When one is discussing gender, equality, or empowerment, the challenge is to look beyond macrogeneralizations while also avoiding a fixation on difference between the places. By arguing that relationships of power can determine the flows of ideas on equality, I do not imply that the North or the South is symbolically and ideologically fixed or that there is a homogeneous body of ideas. However, there are dominant ways of thinking about development in which the West is a referent (cf. Mohanty 2003). 
Nor do the connections between the two places imply a one-way flow. Conversations between them have unexpected effects. The relational analysis calls into question prevailing metaphors and categorical divides while keeping in sight the relationships of power that organize the world. It has been possible to locate each case in its context yet carry out a dialogue between the two across what might be regarded as the development divide.

People in the two locations in India and Sweden were linked by the fact that both were affected by similar discussions on gender and development, although their experiences were not the same. This can be seen in Western influence in policy making on gender in India. But a colonial discourse on oppressed women is also palpable in how Sweden positions itself in terms of gender equality, as unique in its relations to others. Though Sweden was never a colonial power itself, the contemporary effects of colonization and of immigration to Sweden clearly reflect thinking about the other (de los Reyes, Molina, and Mulinari 2002). Women in Nayagarh, India, gave substance to wider social debates about women and development in unanticipated ways as they took up issues of discrimination and argued for their cause. In Drevdagen, Sweden, the categories of development and gender equality were used to stall change and disregard inequalities.

In the following sections, I move between different geographical levels as I analyze the two places. The first section is a discussion of public policy making and dominant discourses on gender equality and empowerment that framed the women's activism. I study how national discourses and policies on gender, equality, and empowerment played an important part in forming women's subjectivities and modes of identification. In the second section I provide background on the two places and the women's organizing. In the third, I go on to examine how beliefs about gender, equality, and empowerment are given meaning in the material and discursive practices of the men and women in both study sites. In the fourth and last sections, I analyze how these beliefs influenced dimensions of difference in conceptualizing collective and individual agency and in what counted as gender equality or empowerment in the two contexts, and I trace the connections between the two places.

\section{Jämställdhet in Sweden and empowerment in India}

Striking in discussions about gender in Sweden is how male dominance and the different treatment of women and men have become illegitimate as a basic social principle, both in state policies and in wider discourses in society. Discourses of the new fatherhood and gender equality are cul- 
turally dominant today, regardless of actual practice (Plantin, Månsson, and Kearney 2000). "Contemporary mainstream researchers, decision makers and journalists often describe the transformation of Sweden following the introduction of general suffrage as having created a society which is both more egalitarian and more women-friendly than most others. Public policies aim at making it possible to achieve gender neutrality, defined as equal opportunities for women and men in the labour market, the family and political life" (Gustafsson, Eduards, and Rönnblom 1997, 42). Sweden's path to gender equality has been through the labor market, and women's presence in the labor force has been an accomplishment. Gender-neutral policies were so effectively promoted as the way to achieve gender equality that gender equality has become conflated with neutrality. The state is seen as the main source of economic and moral support for gender equality through its welfare policies and through the public-sector labor market, which employs large numbers of women.

A sense of uniqueness, of having come far in questions of gender equality, permeates Sweden. The subtle yet significant presence of the notquite-developed South is evident in how gender equality is defined in policy but also in the subjectivities of women in the Swedish village I worked with, as I demonstrate below. The following lines taken from the Swedish government memorandum on gender equality epitomize this thinking:

We in Sweden have come a long way compared with other nations, yes, in fact, we are far ahead of the rest of the world. We are glad to share our experiences; we are glad to export our Swedish model for gender equality. But this, our first place, should not lead us to think that we are done. As yet there is a lot to be done in many areas. . . .

We all have a responsibility to ensure gender equality. All the ministers, all the parliamentarians, and Swedish citizens in general must feel like Sweden's gender equality ministers. (Integrations och Jämställdhets Departmentet 1999, 6) ${ }^{1}$

The nationalistic tone in dominant policy and research discourses on Sweden's exceptional record on gender equality has led to a line of feminist argument that claims that the emphasis on gender equality has shifted attention from the real problem, that is, discrimination against women. The word for gender equality, jämställdhet, that gained currency in the 1990s is considered problematic by several feminists. The basic reason,

${ }^{1}$ All translations from the Swedish are my own. 
argues Malin Rönnblom, is that a word symbolizing a vision is being used to name a problem $(2002,213)$. The term is infused with positive connotations and with a focus on goals and aspirations without naming the group that is disadvantaged. This consensus term (Tollin 2000) is used to discuss and explain power relations between women and men and is linked to democracy and justice. Since it refers to a vision, there is a great deal of variance in how the term is interpreted in practice. To speak of injustice in society by linking power and gender becomes difficult when the official word available is a description of a political ideal and one that emphasizes harmonious interdependence. Yet sexual difference is implicit in political discourse, not least in the framing of jömställdhet, which, in contrast to jümlikhet (equality), is a term used specifically for equality between men and women. Thus, a discourse is created where the rhetoric of equality and assumptions about political decision making as a genderneutral activity conceal the existence of a gendered political order and the continued subordination of women (see Gustafsson, Eduards, and Rönnblom 1997).

Problematizing this further, postcolonial feminist writers in Sweden maintain that jämställdhet has been used to distinguish Swedes from immigrant populations and has been established as a basic part of the Swedish self-image, in relation to the rest of the world as well as to the immigrant populations (de los Reyes, Molina, and Mulinari 2002, 306). ${ }^{2}$ According to Diana Mulinari and Anders Neergard, Sweden has long been characterized by a form of welfare state nationalism that is based on a "wepride" $(2004,210)$ in contrast to a world that is created as irrational, chaotic, and filled with conflict. They write that the image of the generous and tolerant Swedish identity has been weakened in the past twenty years in the context of the shrinking welfare state and through events such as the Palme murder, the Göteborg fire, and Nazi murders that have acquired symbolic significance. ${ }^{3}$ Mulinari and Neergard (2004) write that against

\footnotetext{
${ }^{2}$ Some researchers in Sweden believe that a postcolonial perspective (where race and ethnicity play an important part in the conceptualization) is important to understanding Swedish society. For example, in their book Sverige och de andra (Sweden and the others), Mc Eachrane and Faye (2001) write that although Sweden has never been a colonial power, the Swedish self-image has been formed by being inscribed into the cultural history of the West. This self-image has inevitably been colored by colonialism in Sweden's relations to other non-Western countries and in its relation to its nonwhite others (such as immigrants to the country).

${ }^{3}$ The killing of Prime Minister Olof Palme in 1986 gave rise to a number of conspiracy theories and the brief arrest of a right-wing extremist and a Kurdish dissident living in Sweden. In 1999, the picture of Swedish neo-Nazis as working-class youths upset over immigration
} 
this background, jümställdhet, or gender equality between men and women, is the only successful cultural product (de los Reyes, Molina, and Mulinari 2002) that can be used as an ethnic marker against those who are constructed as "the other."

A diffracted image of gender equality in Sweden appears in the Indian national context. Here gender is "an 'issue' in another sense of the word: a crisis, a problem, a scandal" (Sunder Rajan 1999, 2). Rajeswari Sunder Rajan traces this conceptualization to the milestone report on gender equality published in 1974 (Towards Equality, produced by the government of India) that pointed to the skewed demographics of the female/ male population ratio, the decline in women's workforce participation levels and in levels of literacy and health, all of which showed how poorly women were faring in independent India. Gender gaps in development, employment, nutrition, land distribution, and inheritance became impossible to overlook. Thus, across the board in government concerns, social movements, discourses, disciplines, and sites of action, gender began to figure as an issue as well as a category of analysis (Sunder Rajan 1999). Debates on gender have meshed directly with and have actively constituted prevailing conceptions of India's national identity, conceptions that include the reconfigured primacy accorded to development (John 1999, 110). The fate of women became linked to mainstream development agendas: "Development experts cite 'gender bias' as the cause of poverty in the 'Third World'; population planners declare their commitment to the empowerment of Indian women; economists speak of the feminisation of the Indian labour force. . . . There is a sense, therefore, in which the new visibility is an index of the success of the women's movement. But clearly this success is also problematic" (Tharu and Niranjana 1999, 494).

Increasingly, women are represented as efficient workers and economic subjects, reflecting a national discourse and international influences. Nevertheless, policies and programs still treat women as needy, and images of victimhood and incapacity persist. The help provided to women, such as family planning programs or sanitation, is in keeping with stereotypical ideas about women's roles. However, there have been unexpected exceptions. Awareness-raising programs have led women to organize against oppressive state organs, resulting in "a peculiar situation of the state sponsoring women's struggles against itself" (Lingam 2002, 317).

and often provoked by violent immigrant youths was shattered as a result of neo-Nazi attacks against journalists, trade union activists, and homosexuals, most of them native Swedes. The Göteborg fire in October 1998 took place in a disco; several young people died, most of whom were immigrants. There was tension because many believed that Swedish youths had set the fire. Eventually four Iranian men were found guilty. 
Outside influences on how gender is construed can be felt more tangibly in India than in Sweden, reflecting an overt power difference between the North and South. International donor agencies and nongovernmental organizations are important in shaping policies and development activities. Women's marginalization from centers of power is widely discussed, not least because the large amount of development literature has helped to create a space for so-called women's issues. International feminist networks have been able to influence where and how various forms of development aid are channeled. Northern aid agencies often demand a gender perspective or gender component to their programs in the South. Although the validity and the effects vary, they often succeed in treating women as a special category. This has led to the co-option of such agendas by bureaucracies. Gender becomes a technocratic measure, resulting in its depoliticization as it is turned into a matter of monitoring and planning rather than struggle (Baden and Goetz 1998). Empowerment through self-help groups or support for women's groups has often been bureaucratized and interpreted by government and nongovernmental organizations or aid agencies in a simplistic manner. Underscoring these measures is an assumption of inequality and of an obvious male dominance that characterizes much of the discussion on gender. Formal structures such as administrative arms of the government, forest committees, or village organizations evidently lack women and are not necessarily seen to represent women as a group.

Images of the gender-neutral and gender-equal Sweden, as opposed to the patriarchal nature of the state and society in India, have played out in various ways in women's organizing in both Nayagarh, India, and Drevdagen, Sweden, in their respective modes of self-identification as well as in the actions taken by women in both sites. When seen in relation to each other, the two cases make clear women's possibilities for action in different national and discursive settings.

\section{A house of dreams and many small threads}

Drevdagen is situated in the sparsely populated region of western Sweden, with modest service provisions and few avenues for employment. The village is ethnically homogeneous with no major differences in wealth and education among the inhabitants. Since the 1950s, the migration of people to urban centers has been a cause for concern. To counter these trends, men and women in Drevdagen formed a village association in 1995. The women took up what they called the social issues: the village shop, the 
school, tourist initiatives. The men spearheaded the struggle to get rights from the state to manage surrounding forests to generate employment. This struggle for the forests brought them in touch with some male colleagues at my university. My colleagues' interest in the forests led the men heading the association to focus on the forests to the neglect of the issues that the women had taken up. The women also found it difficult to make themselves heard on questions concerning the forests. This led most women to lose interest in the association. When I first visited the village in 1998, my desire to conduct a participatory inquiry with the women on issues of development and local forest management coincided with their need to meet and discuss village development and the forests on their own terms. They transformed the space of the inquiry to create what they came to call the kvinnoforum, a women's forum. The kvinnoforum became a space where women from their village and beyond met, socialized, supported one another in their projects, and worked for what they called a "living countryside." We met in an abandoned building where the village shop used to be and that the women had renamed the "house of dreams," a space from which they would make their dreams come true. The forum and my research on the process as a participant member led to resistance from the men in the village association and from my colleagues at the university. ${ }^{4}$ They felt that the women's organizing disrupted

${ }^{4}$ Between 1998 and 2008, the research process went through a number of cycles. In 1998 I interviewed twenty-three women and six men in Drevdagen. This was followed by a collaborative inquiry with the women (1999-2000). My role in the inquiry was to share facilitation, document the process, interview individual women, and contribute with examples and theories to discuss together. We met every six weeks over a period of two years. I kept a record of the stories, minutes, and discussions. After 2000 we met less frequently in the group and mainly to discuss what I was writing. The most recent phase of our process (2007-8) was the analyses of our different experiences of the research in two articles, one by the kvinnoforum (Bergelin et al. 2008) and one by me (Arora-Jonsson 2008). In my PhD dissertation (Arora-Jonsson 2005) I used material generated from my field journals, interviews with other women and men in Drevdagen, anecdotes of actions taken, and reports of our get-togethers and discussions in the group, as well as my material from Nayagarh. This participatory approach provided me with unusual insights into how wider politics of gender equality were shaped at the village level. The politics in Drevdagen resonated with the analyses of gender equality, a politically correct gender discourse, and a sense of uniqueness about Sweden described by other researchers as well as with accounts of resistance encountered by women-only groups in other parts of Sweden. Such long-term participatory research and the analytical practice of reversing the gaze of collective and individual subjectivities in the process of organizing (described in detail in Arora-Jonsson [2005]) also provided unusual insights into the gendered relations of everyday life in the Swedish countryside. All quotations from Drevdagen in this article are from the group discussions and other conversations during 
gender harmony in the village. My colleagues pointed out to me that this was not the global South and that gender was not a problem here in the same way that it is there. In their opinion, interference in their forest project and my writing about what they considered to be criticism by a few disgruntled women could jeopardize their chances to effect larger forest policy changes. ${ }^{5}$

Such tensions shadowed the women's organizing and become more obvious when seen in relation to a similar process in Nayagarh, India. The women in Nayagarh were organizing themselves in microcredit groups as part of a women's development program when I came to the villages in 1998. ${ }^{6}$ Since the 1980s, a community forestry movement had spread across the entire district. The villages had been protecting forests, and this had resulted in considerable forest cover. Women had been active participants in the movement, especially since the male leaders advocated what they called "total development," which included social reform, and greater involvement of women. ${ }^{7}$ As the movement took the shape of a formalized network of forest organizations, it began to get a small amount of funding from Oxfam. The number of forest protection networks expanded, and they together formed the Nayagarh forest federation. Women, who had never formally been part of the decision-making groups, became conspicuously absent. The forestry networks came to be dominated by elderly men from the general castes. ${ }^{8}$ Oxfam began to provide funds for a women's development program to bring women into the forest organizations. The training for this took the shape of classes on tailoring, family planning, and sanitation and eventually, in 1994, in assistance in setting up women's groups, mabila samitis, to carry out a microcredit program.

While some mabila samitis were groups on paper only, others became

our get-togethers as part of the collaborative inquiry between 1999 and 2000 . The transcripts are with the author. All other quotes from individual interviews and conversations are specified in separate footnotes.

5 Telephone conversation with one of my colleagues at the university, Uppsala, October 1999.

${ }^{6}$ In Nayagarh (first in 1993-94 and then in 1998-99), I carried out group discussions and individual interviews (which I filmed) with women and men in the villages, attended meetings, and interacted informally during my stay there. All quotations from my research in Nayagarh are taken from group discussion with mabila samiti members between 1998 and 1999 unless specified otherwise. Transcripts are with the author.

${ }^{7}$ Interviews with two of the founding members of the movement: Kesharpur, Orissa, March 1993, and Bhubaneswar, Orissa, July 1993.

8 The general castes consist of the Khandait, Chasa, Kumithi, and the Telegus among some others; they are low in the caste hierarchy. 
informal credit centers. Some went beyond the agenda of the program and transformed the collectives into a space from which they could take action on behalf of the village and on behalf of themselves as women. They challenged how funds were spent and how decisions were made by the forest organizations. Like the Swedish women, who also needed a physical place to call their own, one mabila samiti set up an herb garden that was their own space materially as well as symbolically. It was the only place where the women could gather and discuss issues outside and not in someone's home. In Nayagarh, the women's groups had to navigate a more heterogeneous terrain. Differences in age were complicated by caste and class differences. The groups were normally organized along lines of caste and also according to age. Despite these differences, the women were conscious of the strength they derived from the existence of other such groups. As one woman put it, "small, small threads make a big piece of cloth . . . small tools make a big factory."

Women from a number of mabila samitis in neighboring villages related how they organized themselves and forced several landowners to part with land needed to build a road to the village. The women lay down in a public space on a hot summer morning in May and refused to move until the landowners agreed to talk. This resolved a fifteen-year-old problem that, as the women mentioned frequently, the men had been unable to resolve in their committees. Stories from this incident and others, such as that of women protecting forests from loggers and miners and forcing district officials to provide services that were rightfully theirs, contributed to building up their collectives as political and not merely social forces. As one of the coordinators of the women's program said, "What is the point of saving money and making mixtures [snacks] when everything else stays the same?"

The women's actions evoked mixed reactions in the villages. The forest federation aimed to integrate the mahila samitis into the federation (not without opposition from many men). Even among those who supported the women, several believed that there was little that "a group of illiterate women could do without guidance from the men." But the women thought differently: "We can't keep waiting for them to decide when they feel that our issues are important to take on." Tensions rose when they began to take up questions of violence and dowry and to speak of the need for a women's federation parallel to the men's committees. The mahila samitis and especially the staff of the women's program active in

\footnotetext{
${ }^{9}$ Interview with one of the officeholders of the forest federation, February 1999. However, not all the women were illiterate, just as not all the men were literate.
} 
coordinating the groups began to meet with resistance from the men in the forest organizations.

\section{Modes of self-identification}

Meeting in the kvinnoforum in Sweden or in the mabila samitis in India was neither natural nor self-evident. Both were spaces that the women had consciously constructed. The making of these spaces was not only the result of the women's social location. Social boundaries between them-such as class, age, and their place in the labor force or caste-were not always erased as the women sought to organize together, but these boundaries were often acknowledged as the women found ways to relate to one another over them. The experience of collectivity proved to be their strength rather than a sign of their weakness as individuals who were unable to act individually and independently. However, a fear of being seen as weak and incapable as a result of choosing to organize in their own group troubled the women in different ways in both study sites.

Ideals about equality and about the gender neutrality of common spaces were present in Drevdagen in several ways in the women's own doubts about organizing separately and in the opposition to their organizing. It became apparent that the women saw themselves as autonomous, but they also talked about the male dominance ingrained in much of the föreningsliv, the associational life of Swedish villages. However, none of the women thought of themselves as being personally disadvantaged simply by being a woman. On personal and individual levels, they saw themselves as equal with men. In spite of this (or perhaps because of this), when it came to forming the women's group, there was a certain amount of tension. Taking on an identity as a member of a women's group was uncomfortable for some since officially there were already neutral committees in the village in which both men and women could be involved.

To complain in what was regarded as a gender-equal system could be seen as being hysterical. For the women in Drevdagen, the ideas on equality thus functioned as a form of self-restraint, preventing the women from openly voicing their discontent if they were excluded or discriminated against. The women themselves spoke of being strong women. For them, acknowledging discrimination and thereby assuming the role of a victim would be antithetical to that identity. In justifying their group, the women chose consciously to build on their strengths rather than emphasize disadvantage. They considered themselves equal with the men. This did not mean that they did not see disadvantage, but that it expressed itself differently for different women. Age and their life experiences (the kind of 
employment that they had or their level of education) made a difference in how they regarded and dealt with feelings of injustice. Some women who had lived in the city before felt that it was easier to deal with municipal authorities than others who felt that the authorities regarded them as backward, rural women. The women's relations to the men in the village were also varied. They felt it important to emphasize their differences. There was thus a tension in acknowledging unequal power relations. It meant acknowledging discrimination, which could imply loss of self-worth and power in a system in which everyone was supposed to be equal. Tensions such as these sometimes made it difficult for the women to articulate a common identity (or rather the identity needed to be reaffirmed each time) or to make their activities and discussions more stable and continuous. Their need for informality stemmed partly from this. It put together women who were different and wanted to do things differently. For example, some felt that it was important to involve men in their forum whereas others did not.

In comparison, the women's identity as members of women's groups in Nayagarh was not in question. The women claimed that it was through their group that they saw themselves as making a difference. They were working purposively for activities that needed organizing. They were doing more than just going about their daily chores, which they do at the individual or family level and which are often governed by tradition and custom (regulated by the men and, for the younger women, also by older women). In the groups they communicated and acted together for something that concerned most of them or when individual women needed the support of the others. They seemed to have more of a sense of identity as a coherent group in comparison to the women in Drevdagen.

The Swedish women drew on a repository of meanings that existed outside them as they described their experiences. Initially, in get-togethers they sometimes explained women's lack of participation in village and forest committees as a result of low self-esteem. However, nobody spoke of herself as having low self-esteem. This image was always used to describe someone else: the old-fashioned, shy, and traditional woman, an image that the women saw themselves working against. They did not see their own roles as mothers or wives as conservative, a label they applied when discussing the previous generation.

I described my research in Nayagarh to members of the kvinnoforum, prompting a discussion on what it meant to be modern in India with respect to gender relations and equality. One woman remarked, "I have heard that in India women have become stronger . . . have developed quite a lot, ever since India has become modern. Perhaps that is why they 
have been able to do these things together." Another woman was offended at being associated with the women in Nayagarh. "But we are different," she told me. "We are working women." 10 The Swedish women's subjective positions as modern women were built very much in contrast to the earlier generation as well as to the not-so-modern women of the third world who were not working women in the same sense. Not surprisingly, this attitude was absent in the stories of the older women (in their sixties, seventies, and eighties) who spoke of the strong women of the past, women in their mothers' generation who had moved to these mountains and built up farming communities.

The importance of being working women recurred often in our conversations. The women's involvement in the workforce, mostly in service positions, was an important part of their identity as independent women, reflecting Sweden's efforts over the years to bring about gender equality through the labor market. ${ }^{11}$ This was an important component of their status: being modern working women provided a sense of liberation from the drudgery of the past.

Yet, in the stories of the younger women (ages 30-60) in the forum, contradictory images abound. There were tensions in how the women regarded their working lives. They were proud of working outside the home, but many felt confined by not being able to do community work for the village and by having to travel long distances to work. Although many worked outside the home, they also spoke of not being able to do the work they wanted on their own terms and of being trapped in the jobs they had. Their involvement in the workforce-which in some respects provided them with economic freedom and an identity-also made them prisoners of a system over which they had little or no control. Several worked in the health sector and spoke of their difficult positions and the fact that they "were made to do all kinds of strange things" in the bouts of rationalization of health care services undertaken by the state during the 1990s. Many women insisted that motherhood, in comparison to work, was a relationship that was rewarding, in which they were appreciated. This was not a glorification of motherhood but reflected the practicalities of their lives and was "central to many women's ideas about themselves" for which many felt there was "little or no validation in dominant discourses" (O'Connor 1998, 131). A strong notion of mothers as pri-

\footnotetext{
${ }^{10}$ Interview with a woman in Drevdagen at her home in April 1999.

${ }^{11}$ Almost ninety percent of Swedish women work in the labor force. Despite this involvement in the labor force, Sweden has one of the most gender-segregated labor forces in Europe, with women in lower-paid and part-time professions.
} 
marily responsible for children in Sweden is juxtaposed with ideas about gender equality, employment, and dual responsibility (Elvin-Nowak and Thomsson 2001). Dual responsibility is a strong discourse in Sweden regardless of actual practice (Magnusson 2001). For some women, living and working in the village meant that negotiations over the use of their time and juggling responsibilities and work were for their own benefit rather than that of their employers, suggesting that to work in paid jobs was not always rewarding.

For the women in Nayagarh, discrimination was self-evident. They linked their disadvantage in the villages to wider orders beyond their immediate or local context. Mamta Tiwari, one of the field organizers for the women's program, expressed this in a report: "The government has reserved $33 \%$ of seats for women. It may rise to $50 \%$ in future. But this reservation will not solve our problem. Unless we represent our problems effectively. Women should not only conduct environmental work, they should protect themselves, build up awareness in society. The purpose of the mahila programme should not be only confined in the discussions, meetings, rather it should be translated into action" (Tiwari n.d.).

\section{Dimensions of difference}

The women's modes of self-identification were reinforced by several dimensions that bring out the contextual differences between the two places: the formality or informality of the groups, the rhetoric they used, and the ways in which they took action. Being publicly women, that is, presenting themselves formally as women's groups, was possible for the women in Nayagarh in a way that was not for the Drevdagen women. Since the mabila samitis were part of the women's development program, they followed certain rules and regulations: they had officeholders, documented their activities, and carried out economic activity together. But what really made them formal was that they presented themselves as a women's group and were accepted as such by the rest of the village. The mabila samitis also provided a separate space sanctioned by the forest organization and the village. The women's program accorded them a legitimacy that the women would not have had otherwise. It drew them together outside their households into a public space sanctioned by the community and the state. In acquiring even limited visibility as a formal group, the women had nondomestic reasons to meet, to establish linkages, and perhaps to build nascent ideas of solidarity (see Krishna 2004, 33).

The formality of the program gave the groups the opportunity to become stable entities within the village (for a while) and to link up with 
other groups. The mabila samitis differed from one another to the varying extent to which they were active and in terms of the questions with which they chose to work. Their formality sometimes resulted in greater bargaining power for women vis-à-vis other groups such as landlords, forest committees, violent husbands, or in-laws.

In Drevdagen the women found it necessary to work informally. They had few prospects for influencing discussions in the formal structures on questions important to them. The issues they took up were often considered subordinate to what were regarded as more important questions. The men in the village associations worked hard to maintain existing power relations by asserting the gender neutrality of common spaces. "Nobody has stopped the women from attending the village associations," retorted one of the men in the association when he was told that many women felt apprehensive about attending meetings. ${ }^{12}$ For the women, it was difficult to challenge a system that was suffused with notions of equality and welfare for everyone, that existed under constant threat from the urban center, and where there was a culture of self-imposed guilt at going against the order. Speaking of discrimination or gender made you someone who was looking for problems. It was against village harmony. This was reflected in the women's ambivalence about speaking (or limitations in being able to speak) from within or as an all-women group. It was not as if disadvantages for women were not recognized at all. But as the quotation above makes evident, the problem was individualized. Women who did not attend meetings or speak out were considered lacking in self-confidence, disinterested in village affairs, old-fashioned, or passive. It was made into the problem of individual women and not one of an order of gender and power. In this conception, there were other "normal" ways of dealing with problems that women in the village may have with certain men, through proper channels. Formal equality, however, precluded an analysis of substantive inequality. This was one reason for the need for informality. While in Nayagarh it was through the formal nature of the group that the women were able to wield greater bargaining power vis-à-vis other groups, in Sweden it was the group's informal nature-its not really being a group at all, nor being a women's project-that was important. The kvinnoforum came into being whenever the women met rather than being a stable entity. This strategic informality made the kvinnoforum more difficult to pin down and oppose. The informality enabled the group to be more inclusive of different women and to take up a range of issues.

12 Discussion with two men and one woman about the women's dissatisfaction with the village association at the woman's home in Drevdagen, June 1999. 
The women in Nayagarh often got their demands met by confronting formal authorities such as male landlords or district officials, as in the cases described above. By taking action publicly, the women were demolishing the myth of being victims and beneficiaries as they demanded what they considered rightfully theirs. They communicated their message in a bodily way, exhibiting bodies that are otherwise meant to be confined to the home. By taking part in the action, they affirmed their own identity. Although some of these demonstrations initially were started by one mabila samiti, women from other castes and villages also joined in, making their identity as women (rather than as caste members or village residents) important for the moment. As Zygmunt Bauman writes, "In action one can be a victim without shame" $(1995,73)$, and the women of Nayagarh were using and demolishing their victimhood in these terms.

Politics in Drevdagen did not have space for such action. Similar actions by women would be seen as embarrassing because women in Sweden were understood to be equal, definitely not victims, even though they were regarded as passive by both men and women. The importance of the women's bodies in Nayagarh and the way in which the women made use of them are significant. In Sweden, in an assumed neutrality of male and female, the implications of the body are to be denied. Here it was something far less dramatic, merely meeting as women, that became controversial. The collective brought to light unequal gender relations in Sweden in a way that was already obvious in India. Perhaps that also explains why it appeared more threatening. Difference was given a political meaning.

In keeping with this was a noticeable difference in the rhetoric used by the mabila samitis in Nayagarh and by the kvinnoforum in Drevdagen. There was a certain self-restraint in the language in the kvinnoforum. Although their actions suggested that the reason for organizing was the need for this space as women, the women were quick to emphasize that they were working for the benefit of the village and its development. Except for one occasion, their reticence at the prospect of publicly challenging male domination and exclusion from decision making in the village association was the result of an effort to not draw undue attention to themselves as women-a position that would make them vulnerable in a society built on notions of neutrality. ${ }^{13}$ Nor did they speak out publicly as a women's collective, unlike the women in Nayagarh.

The women's modes of action in both places were conditioned by the role of external intervention and by the village men's varying responses to their organizing. Ideals and discourses about gender relations were

${ }_{13}$ This was a strategic move that may be seen as the exact opposite of strategic essentialism. 
reflected in the images the women had about the men. When I asked the women in a Nayagarh village what made them successful as a group, one answer was, "Our men are good. The men in other villages get jealous when their women get more advanced and try and stop them from acting together." This was contradictory to the views of women in the kvinnoforum. They often spoke of how old habits die hard, implying a backward-looking view on gender relations among many men in the rural areas. They compared the village men to my colleagues working with the forest project. The women believed that the city men did not know about the discrimination in the village, would not behave in this manner themselves, and would do something about it if they did know. ${ }^{14}$ There was a belief that times had changed and that everyone was in fact equal. The unequal relations that kept recurring were regarded not as a reflection of present values but as remains of the past.

Although not quite indulging in gender wars, the married women in India were much more outspoken about expressing conflictual relations with the men in their households and villages. In Sweden, personal relationships with male partners were rarely the subject matter of group discussions. When they were, they were characterized as a love contract (Magnusson 2001), where relations are negotiated through love, making the relationship personal and unique. This is not to say that there are no wars in Swedish households or no love in Indian ones. Rather, these images are descriptive of normative ways of talking about male-female relations. Marriage in India is more a social arrangement than only a private matter between the couple, as it is regarded in Sweden.

It is necessary to theorize not only the separate social interests that women's groups may have but also the deep interdependencies between men and women, which are vital for understanding gender relations. Differences in the men's responses were as important as the differences among the women and had a role in shaping women's activism. In Sweden, many projects spearheaded by the women could be carried out because of the support of men and women in the village. Both in Sweden and in India there were men who believed that the women needed their own groups. In the view of the Swedish women, there was a generational difference in this respect among the men in the village. It was considered easier to speak to the younger men. It was through younger men, often relatives, that the women sometimes tried to influence association meetings. The

\footnotetext{
${ }^{14}$ Unfortunately, not only did the men from the university know about these discriminatory practices, but they participated in making women's efforts to resist them irrelevant by referring to them as personal and as village politics.
} 
opposition expressed by some of these younger and "good" men (to use the terminology of the women in Orissa), however, contributed to the uncertainty among the women. These men's hostility may have sharpened the sense of discrimination. It contradicted the commonplace assumption in Sweden that gender equality is being brought about via a generational shift.

Different men responded in different ways, although they cannot necessarily be placed in different categories (such as age) in their relation to the women's organizing. The male leadership of the forest organizations in Orissa, mainly the older generation, spoke of the need to make the women aware, to impart training. The younger generation (though far from all) spoke about needing to involve women in the forest federation for reasons of both efficiency and equity. The Oxfam officer responsible for the funding of the women's development program also held this view. Men's response to the need for the women to have their own group depended on the particular situation and the men's involvement in that situation, although a normative order was also being negotiated. For example, in Drevdagen, the younger men in the association spoke about the importance of women's networks and considered it important to work toward gender equality. Yet the presence of a kvinnoforum in their own village was deemed dangerous, especially if it interfered in forest matters, traditionally a male domain. Women's activism in Nayagarh was sometimes aided by the men ("our men are good"), and at other times it was a response to violence against women. Forest committee members at the forestry offices often invited me to come and see how well the mabila samitis in their villages were working. This did not necessarily mean that they believed in them for the same reasons as the women, but it does indicate support for the women's organizing. As the coordinator for the women's program said to me, "As it is now, some men are supportive in some places while in others they do not want the women to get together or go for training camps or get-togethers. They feel that the women just go there to eat and get smart and then destroy the household. They are afraid that the women won't listen to the men after having organized. Mahila samitis can be strong if they are supported by the men." 15 The development agents who worked with the men in the communities in Drevdagen and Nayagarh also happened to be men. In Drevdagen, the development practitioners insisted that women were included in the village associations. However, they regarded the women's critique as being a

${ }^{15}$ Interview with the women's groups' coordinator at the Office of the Forest Network in Kesharpur village, Orissa, February 1999. 
result of personal politics that the women needed to be able to solve with the men in their village. In Nayagarh, although the development practitioners wanted to support the women in the mabila samitis, they felt unable to relate to them directly instead of through village organizations. But for a brief period the women had support in their organizing from Oxfam-funded programs implemented through the forest organizations.

The women's relations with the men in their villages once again reflected larger discourses in their societies. Nayagarh was considered male dominated, and individual men who were different were seen as progressive. In Sweden, regarded as a leader in gender equality internationally but also in its own image, men in rural areas who exercised power over others were seen as relics from the past. This power, however, is not a phenomenon of the past but is rooted very much in the present. References to the past to explain unequal relations make acceptable inequalities that are embedded in and have their own history in existing relations of power.

\section{Women are like boats: The conundrums of personal and collective agency}

Studying the trajectories of the two groups in relation to each other directs attention to how the personal and the collective take shape in different ways. One of the men in the forest federation in Nayagarh said with a sigh that women refused to come to meetings and training workshops unless several were invited together. "Women are like boats," he concluded, referring to the convoys of catamarans that went out to fish in the sea. "They always want to go out together. When they will be able to go out alone, become educated and do things on their own, they will be independent . . . empowered." ${ }^{\prime 6}$ But was it this independence that constituted empowerment for the women in the two places?

Naila Kabeer (2001) writes that one facet of empowerment is the ability to choose. In this sense empowerment may be seen as a somewhat normative idea. The women in Sweden were able to choose (more or less) where they lived, whom to marry, and how many children to have, choices that were not available for many women in India. In that respect, the

${ }^{16}$ Intereview with an officeholder of the Nayagarh Forest Federation at the Forest Federation office, Nayagarh town, Nayagarh district, Orissa, February 1999. 
women of Sweden were already empowered. ${ }^{17}$ But their space for collective agency was circumscribed by the dominant discourse on equality and modernization. The ideal and discourse of gender equality, by making discrimination illegitimate, had the negative effect of creating barriers for what women may or may not do or question in their everyday lives.

In Nayagarh, women's agency was not always recognized. The notion of individual empowerment through modernization was not consistent with the idea of the women organizing in groups. True enough, the women's activism in Nayagarh did not always lead to a better life for them. On a personal level, once home from meetings, they were still expected to cover their heads and not to speak in the presence of older males. These were the same women who had fought for their cause with male moneylenders and forest officials. Their confidence in themselves and their success, in certain instances, did lead to changes in household gender relations, but there was no direct cause and effect. In a draft evaluation report on the community forestry groups commissioned by Oxfam, the authors narrate the story of the president of one of the women's groups whose husband beat her for taking up the cause of a village woman who had been cast out by her own husband (Mitra and Patnaik 1997). The authors use this single case to dismiss what the women were saying or were doing in everyday village life: solving disputes, dealing with violent husbands and nasty mothers-in-law, and working with problems related to dowry. Espousing the idea of the individual empowered woman, they claimed that the women's groups were ineffective in changing gender domination in the home.

Frances Cleaver puts it succinctly: 'As 'empowerment' has become a buzzword in development, an essential objective of projects, its radical, challenging and transformatory edge has been lost. The concept of action has become individualized, empowerment depoliticized" (2001, 37). Third-world feminists have criticized the focus on "a singular women's consciousness" (Mohanty 2003, 81). Chandra Talpade Mohanty (2003) writes that the strategy is to speak from within a collective. Doris Sommer “identifies the 'plural' or 'collective' self of Latin American women's testimonials as 'the possibility to get beyond the gap between public and

\footnotetext{
${ }^{17}$ Interestingly, in the context of Swedish academic or policy debate, empowerment is not a concept used in terms of gender relations or in discussions of equality for women (with some exceptions). A search in the research literature (2004-5) shows that the concept has been used (with some exceptions) primarily in research with disabled people; in the context of immigrant women; in some cases in byggforskning (building research), mainly in the case of immigrant settlements; and in business management literature.
} 
private spheres and beyond the often helpless solitude that has plagued Western women even more than men since the rise of capitalism"" (Mohanty 2003,82 , quoting Sommer). Collective organizing may seem to jeopardize gains made by individual women who are able to find a place for themselves in the system. But, both in India and in Sweden, acting together on their own terms constituted empowerment for the women at the collective and village levels, highlighting that there is not always a correlate between individual and collective empowerment or between the strategic and the practical.

On the one hand, by regarding women as incapable, the men in Nayagarh held attitudes that limited the women. On the other hand, the experience of discrimination due to poverty gave both men and women a lens through which to develop a structural analysis of certain inequalities and the need for collective action. The men and women here, by and large, were spared the kind of individualism that attributes every inequality to personal failures on the part of the less rewarded. Understanding caste and class discrimination perhaps helps one understand the fact of sex discrimination, and understanding the need for an independent community forestry movement might help one to understand the need for women's groups. This may be one reason (apart from the fact that the women's group was a program that was part of the community forestry movement) why several men active in the movement tended to support the women's groups although they had their own views on how the groups were to function in relation to themselves (cf. Jane Mansbridge's [1999, 300] argument distinguishing support for the women's movement among white and black men and women in the United States). The women's groups tended not to position themselves in opposition to individual men but in opposition to what they regarded as male behavior, especially in cases of violence and dowry, because their men or some men could be good. In their view, development was indeed incomplete without gender. But for them, development was a transformation not only in which women became independent or empowered but in which jealous men became good.

In an ideal world there would be more direct correlation between personal and collective agency that leads to empowerment. However, discrimination takes many different forms, and though it may be systematic, there is not necessarily a cause-and-effect relationship between the personal and the collective or the strategic and the practical. We need to be open in imagining what women's liberation will be like in the multiple spaces in which women may choose to act individually but also collectively. 
Clearly, women in both places worked not only for themselves but also for an equitable society for women and men. But issues of power were highlighted more often in India. As one of the field organizers wrote in a report, "there is no point talking about the forests when women do not have power themselves" (Tiwari n.d.). The Indian women described themselves as a women's group and took up questions that may be seen to be more challenging of gender relations and were more specifically related to discrimination against women in comparison with the women's group in Sweden. This does not imply that power and discrimination were not issues in the Swedish village. Rather, the space for taking up questions of power and discrimination was smaller. But the women were resisted all the same, not because of what they said but because of what their collectiveness suggested.

To organize as women in the village in Sweden felt illegitimate. A rhetoric of collaboration and gender harmony hid unequal power relations. This was reinforced by wider orders of meanings in policy and institutions. Women's organizing became a "forbidden action" (Eduards 2002). An important contextual distinction between the two places is that in India there was a marked perception and acknowledgement of difference whereas in Sweden that difference was expected to be minimized for reasons of equality. It is a contrast not so much in perception of difference but in the response to it.

Although their actions were by no means seamless or noncontradictory, by stressing the need to have their own space the women of the kvinnoforum produced what Patti Lather calls "new configurations of social relations rather than reproduc[ing] . . . the behaviors that instil dominant values in us" $(1991,96)$. The very act of forming the kvinnoforum was an act of interrupting dominant practice, although nothing was said overtly about challenging the status quo. The women's plans and everyday activities such as organizing village festivities or keeping the village clean as part of the kvinnoforum or the mabila samitis were not very different from the work they may have done in the absence of these groups. It was, instead, the structure of the alternative spaces they created for themselves that made their organizing political and caused antagonism. By organizing as women, the women made men visible as men and not as neutral individuals.

The "surprise factor" (Smith and Smith 1983, 114) of experiencing their subordination as a result of a structure that went beyond their immediate relationships was not relevant in the case of the women in Nayagarh, as it was in Drevdagen. The Nayagarh women did not expect to 
have much direct influence over the committees as individual women or over state agencies. They had less to lose and much to gain by speaking from within a women's group.

For several activists and scholars in the Swedish context, violence against women is the perpetuation of male power over women. Maud Eduards writes that in women's collective action related to the body, violence and power are particularly challenging for democracy because it is men who are singled out as responsible, and this in turn because they are men: "The gender power order is revealed in its nakedness" $(1997,21)$. In India, however, this connection is far from simple. In the perception of the women in Nayagarh, mothers-in-law (and other female relatives) were often instrumental in instigating, abetting, and sometimes taking part in violence against a daughter-in-law. The women's organizing in Nayagarh was directed as much against inhumane mothers-in-law as, for instance, against husbands and fathers-in-law.

Men from outside the villages played an important role in both places. Development projects, especially those with participatory approaches, have been criticized for reinforcing unequal relationships by prioritizing those who are most vocal at meetings or by constructing certain male members as "the community" (see Guijt and Shah 1998). As compared to the case in Sweden, however, in India it was permissible for development practitioners to challenge unequal relationships. The reason is that these inequalities are more obvious in India but also, importantly, that it is more permissible to challenge inequalities in a rural, third-world society that is saturated with development discourses and in which inequality is a premise to begin with. Outside intervention did not cause the change, but, based on an understanding of gender inequalities, it provided a little extra space for the women, which some of them used to negotiate power relations. Intervention in gender relations from outside had more legitimacy.

The relational analysis in this article has uncovered new ground by dwelling on the connections between the Swedish and Indian contexts. The connections played out in ways that were contextual but also discordant. Development discourses about oppressed women and the need for women's empowerment in the global South shaped the spaces for conceptualizing gender equality in both sites: in India, a country where assertions for the need to empower its rural women are frequent, but also in developed Sweden, with its self-image of being far ahead in gender equality in relation to other countries. Statements about victimized and incapable women who need help circumscribed the actions of women in India. At the same time, the discussion of male dominance and victimized women gave the Indian women space to bring up discrimination and to 
press for change. In Sweden, the debates centered on equality and participation. This vision of equality encouraged the idea that the system was good, that women just needed to be added to it to make it perfect. The appreciation of being developed was echoed in how women in Drevdagen formed their subject positions as modern working women in contrast to traditional women in the past and in third-world countries as well as in their ambivalence about whether and how much to challenge the system. It was also reflected in the ease with which my university colleagues regarded gendered inequality in environmental management as a problem in the global South but not relevant in Sweden. Crossing space and jumping scale reveal how discourses are reproduced at different levels, from the international and national policy levels to village politics in Sweden and India. The use of the term "development" showed connections in dominating assumptions both in India and in Sweden about what development is and how gender relations ought to be organized in a developed society. My comparative analysis of the gender politics in both places challenges the linearity inherent in discussions of development and modernization, the notion that women's empowerment follows from economic development or that gender equality comes from a linear progression into modernity. The focus on individual equality in Sweden put the onus on women because it made exclusion and discrimination their responsibility. The notion of the individual, empowered modern woman was also held up as an example to follow in India, thus negating the gains made in collective action. The two instances present examples of the travel of ideas and their specific material forms. They reflect the "scattered hegemonies" (Grewal and Kaplan 1994) of ideas about gender equality and development, not only in the South but also in the North.

Department of Urban and Rural Development

Swedish University of Agricultural Sciences

\section{References}

Arora-Jonsson, Seema. 2005. "Unsettling the Order: Gendered Subjects and Grassroots Activism in Two Forest Communities." PhD dissertation, Swedish University of Agricultural Sciences.

. 2008. " "Research sounds so big . . .': Collaborative Inquiry with Women in Drevdagen, Sweden." In Participatory Research in Conservation and Rural Livelihoods: Doing Science Together, ed. Louise Fortmann, 130-45. Oxford: Wiley-Blackwell.

Baden, Sally, and Anne Marie Goetz. 1998. "Who Needs [Sex] When You Can Have [Gender]? Conflicting Discourses on Gender at Beijing." In Feminist 
Visions of Development: Gender Analysis and Policy, ed. Cecile Jackson and Ruth Pearson, 19-38. London: Routledge.

Bauman, Zygmunt. 1995. Life in Fragments: Essays in Postmodern Morality. Oxford: Blackwell.

Bergelin, Åsa, Margareta Emretsson, Anna Lundgren Halvarsson, Ewa Halvarsson, and Anna Ryen. 2008. "För oss är naturen en lisa för själen (Where Peace Comes Dropping Slow): The Forests and Nature for Us." In Participatory Research in Conservation and Rural Livelihoods: Doing Science Together, ed. Louise Fortmann, 146-61. Oxford: Wiley-Blackwell.

Cleaver, Frances. 2001. "Institutions, Agency and the Limitations of Participatory Approaches to Development." In Participation: The New Tyranny? ed. Bill Cooke and Uma Kothari, 36-55. London: Zed.

de los Reyes, Paulina, Irene Molina, and Diana Mulinari, eds. 2002. Maktens (o)lika förklädnader: Kön, klass och etnicitet $i$ det postkoloniala Sverige [Power's various disguises: Gender, class, and ethnicity in postcolonial Sweden]. Stockholm: Bokförlaget Atlas.

Eduards, Maud. 1997. “Interpreting Women's Organizing.” In Gustafsson, Eduards, and Rönnblom 1997, 11-22.

. 2002. Förbjuden handling: Om kvinnors organisering och feministisk teori [Forbidden action: On women's organizing and feminist theory]. Malmö: Liber.

Elvin-Nowak, Ylva, and Heléne Thomsson. 2001. "Motherhood as Idea and Practice: A Discursive Understanding of Employed Mothers in Sweden." Gender and Society 15(3):407-28.

Grewal, Inderpal, and Caren Kaplan. 1994. Scattered Hegemonies: Postmodernity and Transnational Feminist Practices. Minneapolis: University of Minnesota Press.

Guijt, Irene, and Meera Kaul Shah, eds. 1998. The Myth of Community: Gender Issues in Participatory Development. London: Intermediate Technology Publications.

Gustafsson, Gunnel, Maud Eduards, and Malin Rönnblom. 1997. Towards a New Democratic Order? Women's Organizing in Sweden in the 1990s. Ed. Gunnel Gustafsson. Stockholm: Publica.

Integrations och Jämställdhets Departmentet (Ministry of Integration and Gender Equality). 1999. "Jämställdhetspolitiken inför 2000 talet” [Gender equality policy for the decade of 2000]. Swedish Government Memorandum 24. Stockholm: Swedish Government.

John, Mary E. 1999. “Gender, Development and the Women's Movement: Problems for a History of the Present." In Signposts: Gender Issues in Post-independence India, ed. Rajeswari Sunder Rajan, 100-124. New Delhi: Kali for Women.

Kabeer, Naila. 2001. "Resources, Agency, Achievements: Reflections on the Measurement of Women's Empowerment." In Discussing Women's Empowerment: Theory and Practice, 17-57. Sida Studies no. 3. Series ed. Anne Sisask. Stockholm: Swedish International Development Cooperation Agency.

Katz, Cindi. 2001. "On the Grounds of Globalization: A Topography for Feminist 
Political Engagement.” Signs: Journal of Women in Culture and Society 26(4): 1213-34.

Krishna, Sumi. 2004. "A Genderscape of Community Rights in Natural Resource Management." In her Livelihood and Gender: Equity in Community Resource Management, 17-63. New Delhi: Sage.

Lather, Patti. 1991. Getting Smart: Feminist Research and Pedagogy with/in the Postmodern. New York: Routledge.

Lingam, Lakshmi. 2002. "Taking Stock: Women's Movement and the State." In Social Movements and the State, ed. Ghanshyam Shah, 310-34. New Delhi: Sage.

Magnusson, Eva. 2001. "Politics, Psychology, and Gender in Heterosexual Couples: Welfare States as Laboratories for the Future?" Paper presented at the 109th convention of the American Psychological Association, San Francisco, August 25.

Mansbridge, Jane J. 1999. “'You're Too Independent!': How Gender, Race, and Class Make Many Plural Feminisms.” In The Cultural Territories of Race: Black and White Boundaries, ed. Michele Lamont, 291-317. Chicago: University of Chicago Press.

McEachrane, Michael, and Louis Faye. 2001. Sverige och de andra: Postkoloniala perspektiv [Sweden and the others: Postcolonial perspectives]. Falun: Natur och Kultur.

Mitra, Amit, and Sanjoy Patnaik. 1997. "Community Forest Management in Orissa and the Role of Oxfam: A Review." Unpublished draft of report. Oxfam, Bhubaneswar.

Mohanty, Chandra Talpade. 2003. Feminism without Borders: Decolonizing Theory, Practicing Solidarity. New Delhi: Zubaan.

Mulinari, Diana, and Anders Neergard. 2004. "Syster, du är ju annorlunda: Migration, institutionell förändring och kön" [Sister, you are different: Migration, institutional change, and gender]. In Framtiden $i$ samtiden: Könsrelationer $i$ förändring $i$ Sverige och omvärlden [The future in the present: Gender relations in flux in Sweden and the world around it], ed. Christina Florin and Christina Bergqvist, 204-31. Stockholm: Institutet för Framtidsstudier.

O'Connor, Pat. 1998. “Women's Friendships in a Post-modern World.” In Placing Friendship in Context, ed. Rebecca G. Adams and Graham Allan, 117-35. Cambridge: Cambridge University Press.

Plantin, Lars, Sven-Axel Månsson, and Jeremy Kearney. 2000. “Mäns föräldrarskap: Om faderskap och manlighet i Sverige och England” [Men's parenthood: On fatherhood and masculinity in Sweden and England]. Socialvetenskaplig Tidskrift, nos. 1-2, 24-42.

Rönnblom, Malin. 2002. "Ett eget rum? Kvinnors organisering möter etablerad politik" [A room of one's own? Women's organizing meets established politics]. $\mathrm{PhD}$ dissertation, Umeå University.

Smith, Barbara, and Beverley Smith. 1983. "Across the Kitchen Table: A Sisterto-Sister Dialogue.” In This Bridge Called My Back: Writings by Radical Women 
of Color, ed. Cherríe Moraga and Gloria Anzaldúa, 113-27. New York: Kitchen Table/Women of Color Press.

Sommestad, Lena, and Wangari Maathai. 2005. "Fredspristagare: Genombrott för kvinnors betydelse i miljöarbete" [Peace prize winner: Breakthrough for women's importance in environmental work]. Göteborgs-Posten, February 26, debate page.

Sunder Rajan, Rajeswari. 1999. "Introduction.” In her Signposts: Gender Issues in Post-independence India, 1-16. New Delhi: Kali for Women.

Tharu, Susie, and Tejaswani Niranjana. 1999. "Problems for a Contemporary Theory of Gender." In Gender and Politics in India, ed. Nivedita Menon, 494-525. New Delhi: Oxford University Press.

Tiwari, Mamata. n.d. “Progress Report of Women's Group Formation: Initiative of BOJBP" (in English, translated from the original in Oriya). Unpublished report, Friends of Trees and Living Beings, Nayagarh.

Tollin, Katharina. 2000. "Det måste finnas män med för att det skall bli jämställt: En utvärdering av mainstreamingprojektet inom Arbetsmarknadsverket i Västerbotten" [There have to be men for it to be gender-equal: An evaluation of the mainstreaming project within the Labour Market office in Västerbotten]. Report. Umeå University. 
$\begin{array}{llllll}\text { INTERNWEBB STUDENTPORTAL A-Ö Skriv sökord här } & \text { SÖk SÖK SLU-ANSTÄLLD KONTAKTA SLU }\end{array}$

Sulviges lantbruksuniversitet

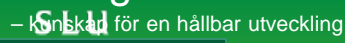

SLU-BIBLIOTEKET

HEM SÖKA LÅNA LÄRA PUBLICERA OM SLU-BIBLIOTEKET

Startsida / SLU-biblioteket
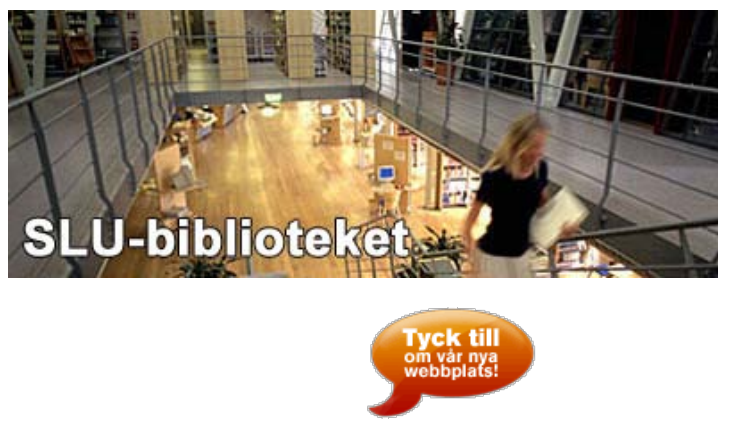

\section{Sök och sökhjälp}

2 LUKAS - vår katalog

$\checkmark$ LIBRIS - nationell katalog

Databaser

(7) Tidskrifter

E-böcker

Söka Samla Sprida

\section{Fixa själv}

3 Se/förnya dina lån

D Skapa lånekonto

(2) Beställ lån/kopior

D Föreslå inköp

(2) Publicera i Epsilon

(3kapa utskriftskonto

D. Fylla på PayEx-konto
Kontakta oss

Öppettider

(2) e-resurser hemifrån

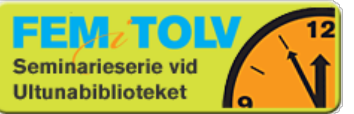

: viktiga resurser

- en guide for informationssōkning»

Guide till LUKAS Tidskrifter

E-böcker Guide till databaser

Epsilon

Digitala kartor

Söka Samla Sprida

Ladda ner SLU-bibliotekets toolbar!

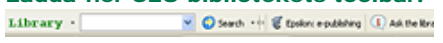

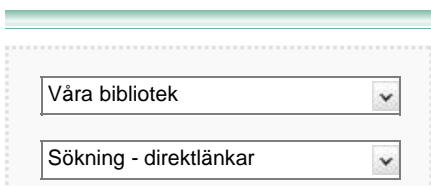

(D För dig som har läshinder

D För dig som studerar på distans

\section{Nyheter}

2010-09-13 - Taylor \& Francis e-

tidskrifter - provperiod t.o.m. 31

oktober 2010

ca 1350 tidskrifter inom humaniora,

samhällsvetenskap, naturvetenskap och

teknik

2010-09-13 - Inderscience Online

ournals - provperiod till 15 oktober 2010

300 tidskrifter inom biovetenskap, humaniora och samhällsvetenskap

2010-08-24 - Springer eBooks provperiod t.o.m. 31 december 2010

Fri åtkomst till mer än 40,000 eböcker utgivna 2005-1010

2010-08-18 - ACM Portal provperiod t.o.m. 9 oktober 2010

2010-08-13 - Policy och

handlingsplan mot fusk och plagiering inom utbildning SLU har antagit en gemensam policy och handlingsplan mot fusk och plagiering.

Information kommer att ges till lärare och studenter under hösten. 